\title{
MOTIVASI BELAJAR MAHASISWA ALIH PROGRAM PADA JURUSAN TEKNOLOGI PENDIDIKAN FIP UNJ
}

\section{Abstrak}

Penelitian ini bertujuan untuk memperoleh gambaran secara deskriptif tentang Motivasi Belajar mahasiswa alih program pada jurusan Kurikulum dan Teknologi Pendidikan.

Manfaat penelitian ini akan menjadi masukan untuk pengembangan kurikulum jurusan Kurikulum dan Teknologi Pendidikan dalam melaksanakan proses belajar dan lulusan pada jurusan Kurikulum dan Teknologi Pendidikan, Fakultas IImu Pendidikan, (FIP) Universitas Negeri Jakarta (UNJ).

Penelitian ini merupakan penelitan deskriptif dengan menggunakan teknik survei.

Hasil penelitian menunjukkan bahwa terdapat hubungan positif antara motivasi belajar dengan hasil belajar mata kuliah Pengembangan Media Pendidikan I ( Uji rxy =0,606 > r tabel = 0,361 pada taraf signifikansi $\alpha=0,05, n=30 ; \quad U j i t=4,03>$ t tabel $=2,76$ pada taraf signifikansi $\alpha=0,05 d k=28)$. Indeks determinasi $=0,37$ atau sebanyak $37 \%$ variasi motivasi belajar memberikan kontribusi kepada hasil belajar mahasiswa alih program jurusan Teknologi Pendidikan.

*) Bambang Sutjipto, M.Pd. adalah dosen Jurusan KTP, FIP Universitas Negeri Jakarta 


\section{PENDAHULUAN}

Salah satu upaya guru agar siswa mudah memahami dan mencerna materi pelajaran adalah memanfaatkan media pengajaran Hampir semua mata pelajaran memerlukan media. Pada kenyataannya tidak semua guru memanfaatkan media, karena merasa tidak mampu merancang dan membuat media grafis. Inilah yang menjadi hambatan meningkatan kualitas pendidikan di semua jenjang dan tingkat pendidikan.

Dengan meningkatnya jumlah guru yang memasuki program strata satu, menunjukkan bahwa ada motivasi berupaya meningkatkan profesi di bidang pendidikan. Pada umumnya mahasiswa yang belajar di jurusan Kurikulum dan Teknologi Pendidikan adalah guru Sekolah Dasar.

Hambatan peningkatan mutu pendidikan dapat teratasi, apabila animo para guru dalam meningkatkan profesi melalui belajar di strata satu cukup besar.

Semester satu tahun akademik 1999/2000 mahasiswa alih program mempelajari mata kuliah Pengembangan Media Pendidikan I ( Media Sederhana), pada mata kuliah ini mahasiswa dibekali teori dan praktek merancang dan membuat media sederhana, dengan tujuannya agar dalam melaksanakan tugas sebagai guru mampu merancang dan membuat sendiri media yang relevan dengan materi yang sedang diajarkan di tempat tugasnya.

Diharapkan agar setelah menyelesaikan mata kuliah ini, mahasiswa mampu merancang dan membuat media sendiri yang relevan dengan bidang yang diajarkan.

Seperti yang telah diuraikan pada latar belakang masalah di atas, maka masalah yang akan timbul adalah sebagai berikut:

Mengapa guru-guru Sekolah Dasar memasuki alih program S1 UNJ, khususnya S1 Jurusan KTP FIP UNJ? Apakah Kurikulum Jurusan 
Teknologi Pendidikan ada relevansinya dengan profesi guru Sekolah Dasar? Setelah selesai mengikuti mata kuliah Pengembangan Media Pendidikan I, apakah mahasiswa akan termotivasi untuk merancang dan membuat media dalam melaksanakan tugas pokok di Sekolah Dasar? Apakah terdapat hubungan antara motivasi belajar mahasiswa dengan hasil belajar mata kuliah Pengembangan Media I?

Dari beberapa masalah yang telah diidentifikasi tersebut di atas, sementara dihadapi berbagai keterbatasan waktu dan dana, maka dalam penelitian ini, peneliti membatasi masalah sebagai berikut:

Hubungan antara motivasi belajar dengan hasil belajar mahasiswa alih program Jurusan Kurikulum danTeknologi Pendidikan, Fakultas IImu Pendidikan, Universitas Negeri Jakarta.

Berdasarkan identifikasi dan pembatasan masalah dapat dirumuskan permasalahan penelitian sebagai berikut :

Apakah terdapat hubungan berbanding lurus antara motivasi belajar dengan hasil belajar mata kuliah Pengembangan Media Pendidikan I mahasiswa alih program Program Studi Teknologi Pendidikan, FIP,UNJ?

Tujuan penelitian ini adalah untuk mengetahui kemampuan mahasiswa dalam mengikuti mata kuliah Pengembangan Media Sederhana dan dapat diketahui gambaran tentang hubungan motivasi belajar dengan hasil belajar mata kuliah Pengembangan Media Pendidikan I mahasiswa Program Studi Teknologi Pendidikan, FIP UNJ ?

Manfaat hasil penelitian ini diharapkan dapat memberikan gambaran yang jelas tentang hubungan motivasi belajar dengan hasil belajar mata kuliah Pengembangan Media Pendidikan I mahasiswa Alih Program jurusan KTP, FIP UNJ, dan sebagai bahan masukan bagi jurusan Kurikulum dan Teknologi Pendidikan, program studi Teknologi Pendidikan. 


\section{KAJIAN TEORI}

\section{a. Hakekat Motivasi Belajar}

Belajar merupakan suatu proses yang ditandai adanya perubahan tingkah laku. Perubahan tersebut berlangsung secara interaksi aktif antara si pebelajar dengan lingkungan belajarnya. Dalam hal ini peserta didik perlu menciptakan dan melaksanakan aktivitas belajar dengan baik, yaitu memotivasi dirinya untuk mencapai aktivitas itu. Dengan kata lain, peserta didik harus memiliki motivasi untuk mencapai perolehan belajar.

Motivasi merupakan faktor yang sangat besar pengaruhnya dalam proses belajar. Hal ini sejalan dengan pendapat Sardiman yang mengatakan bahwa motivasi adalah serangkaian usaha untuk menyediakan kondisi-kondisi-kondisi tertentu sehingga seseorang itu mau dan rela untuk melaksanakan sesuatu (Sardiman, 2000: 73) Dalam hal ini motivasi itu dapat dirangsang oleh faktor dari luar dan faktor dari dalam diri seseorang yang belajar. Kedua faktor ini menyebabkan si pebelajar akan memiliki dorongan yang kuat untuk mencapai kedua faktor tersebut dikenal dengan sebutan motivasi intrinsik dan ekstrinsik.

Motivasi intrinsik merupakan motivasi murni (yang sebenarnya), sedangkan motivasi ekstrinsik merupakan motivasi yang disebabkan faktor luar dari situasi belajar. Motivasi intrinsik tidak perlu dirangsang dari luar, karena dalam setiap diri individu sudah ada dorongan untuk melakukan sesuatu. Bila seseorang telah memiliki motivasi intrinsik dalam dirinya, maka ia secara sadar akan melakukan suatu kegiatan yang tidak memerlukan motivasi dari luar dirinya. Dalam aktivitas belajar motivasi ini sangat diperlukan untuk belajar sendiri. Peserta didik yang memiliki motivasi belajar intrinsik, selalu ingin maju dalam belajar. Keinginan itu dilatar belakangi oleh pemikiran yang positif, bahwa semua mata pelajaran yang dipelajari akan sangat dibutuhkan dan sangat berguna kini dan mendatang. Sedangkan motivasi ekstrinsik diperlukan agar siswa mau belajar. Dalam hal ini pendidik dapat mendorong siswanya agar giat belajar dengan berbagai cara, antara lain menggunakan metode yang bervariasi, 
menjelaskan kepada siswa hal-hal yang dapat dilakukan selama proses belajar mengajar, membantu kesulitan belajar siswa baik secara individu maupun kelompok, merangsang siswa untuk memperoleh prestasi belajar yang lebih baik.

Menurut Weiner dalam Gedler, mengatakan bahwa orang yang termotivasi, prestasinya tinggi dan mereka akan berusaha lebih banyak untuk melaksanakan tugas-tugas. (Margaret E.B G., 1994 : 436). Jadi perilakunya akan diarahkan terhadap keberhasilan.

Dalam suatu kegiatan belajar mengajar, dikenal adanya motivasi belajar, yaitu motivasi yang diterapkan dalam kegiatan belajar. Motivasi belajar (Palardi,1975) memegang peranan penting dalam memberikan gairah, semangat dan rasa senang dalam belajar sehingga yang mempunyai motivasi tinggi dan mempunyai energi yang bangat untuk melaksanakan kegiatan belajare. Siswa yang mempunyai motivasi belajar tinggi sangat sedikit tertinggal belajarnya dan sangat sedikit pula kesalahan dalam belajarnya.(Margaret, E.B.G,1994 : 88)

Hal ini sejalan dengan pendapat Winkel yang mengemukakan bahwa motivasi belajar adalah keseluruhan daya penggerak psikis dalam diri siswa yang menimbulkan kegiatan belajar, menjamin kelangsungan itu demi mencapai tujuan tertentu (Winkel, 1996 : 87)

Jadi dapat dikatakan bahwa motivasi belajar dapat memberikan gairah belajar untuk melaksanakan kegiatan belajar. Peserta didik akan belajar dengan sungguh-sungguh, sistematis, penuh perhatian dan dapat melaksanakan tugas-tugas dengan baik

\section{b. Hakikat hasil belajar Pengembangan Media Pendidikan I}

Winkel mengemukakan pengertian belajar suatu aktifitas mental/ psikis, yang berlangsung dalam interaksi aktif dengan lingkungan, yang meng-hasilkan perubahan-perubahan dalam pengetahuan, 
keterampilan dan sikap.(Winkel, 1991: 36) Sedangkan pengertian belajar yang dikemukakan Olson, belajar adalah menekankan kepada tujuan kegiatan belajar, yaitu memperoleh pengetahuan, pemahaman atau penguasaan melalui pengalaman (Hergen HM, $1993: 2)$

Menurut Gage dalam Dahar, belajar diartikan sebagai proses dimana suatu organisme berubah perilakunya sebagai akibat pengalaman. (Ratna WD,1989: 11) Sadiman menegaskan kegiatan belajar pada hakekatnya untuk mencapai suatu tujuan.(Arief S.Sadiman, $1993: 1$ )

Akhir dari belajar diperoleh suatu bentuk penguasaan dari apa yang telah dipelajari sebelumnya yang disebut hasil belajar. Sudijarto dalam Waluyo mengemukakan hasil belajar adalah tingkat penguasaan yang dicapai siswa dalam mengikuti program belajarmengajar sesuai dengan tujuan pendidikan yang ditetapkan.( HY Waluyo, 1987: 25) Hasil belajar jangka panjang akan dicapai melalui jangka pendek sesuai dengan tujuan pembelajaran dan tujuan khusus pembelajaran.(HY Waluyo, 1987 : 24-25)

Hasil belajar jangka pendek dicapai, setelah pebelajar belajar selama satu semester. Hasil belajar lazimnya berupa nilai prestasi belajar. Hasil belajar bermakna apabila dihubungkan dengan semua faktor yang ingin diketahuinya dan disesuaikan dengan seluruh situasi pendidikan yang dialami. Sukardi menegaskan bahwa hasil belajar merupakan pencerminan daripada kemampuan khusus yang dimiliki oleh seorang dan beberapa siswa dalam bidang studi tertentu.(Dewa K.Sukardi, 1983 : 101)

Pengukuran hasil belajar dapat dilakukan karena pebelajar telah memperoleh pengalaman melalui proses belajar mengajar. Dengan demikian tujuan dari penilaian hasil belajar adalah untuk mengetahui tingkat kemampuan siswa dalam memahami materi pelajaran yang telah disampaikan guru. merupakan pencerminan daripada kemampuan khusus yang dimiliki oleh seorang dan 
beberapa siswa dalam bidang studi tertentu.(Dewa KS, 1983 : 101)

Pengukuran hasil belajar dapat dilakukan karena pebelajar telah memperoleh pengalaman melalui proses belajar mengajar. Dengan demikian tujuan dari penilaian hasil belajar adalah untuk mengetahui tingkat kemampuan siswa dalam memahami materi pelajaran yang telah disampaikan guru.

Pengembangan media pendidikan I merupakan salah satu mata kuliah wajib pada jurusan Kurikulum dan Teknologi Pendidikan. Mata kuliah ini diberikan dalam bentuk workshop, yaitu belajar dalam bentuk praktek merancang dan membuat media sederhana. Media sederhana yang dikerjakan oleh mahasiswa antara lain media gambar, media bagan/irisan, lembar balik dan flashcard (kartu bergambar) yang dapat menunjang proses belajar mengajar di Sekolah Dasar.

Hasil belajar setiap mahasiswa dalam mata kuliah Pengembangan Media Pendidikan I dinyatakan dalam bentuk angka yang diperoleh sesuai dengan tingkat kemampuan membuat merancang dan membuat media

Pengembangan Media Pendidikan I merupakan salah satu mata kuliah wajib pada jurusan Kurikulum dan Teknologi Pendidikan.

Hasil belajar setiap mahasiswa dalam mata kuliah Pengembangan Media Pendidikan I dinyatakan dalam bentuk angka yang diperoleh sesuai dengan tingkat kemampuan membuat merancang dan membuat media sederhana. Pencerminan hasil belajar dari masingmasing mahasiswa berpedoman pada angka penilaian yang telah dibakukan dalam Buku pedoman Akademik UNJ.

\section{c. Hakikat Media}

1. Pengertian Media

Manusia adalah makhluk sosial, antara manusia satu dengan yang lainnya saling menjalin hubungan atau 
berkomunikasi. Proses komunikasi akan menjalin hubungan suatu hubungan tiimbal balik. Adapun proses komunikasi yang dikemukakan Berlo Dalam Teknologi Komunikasi Pendidikan : Sumber pesan (S) menyalurkan pesan melalui media (M) disampaikan kepada penerima pesan $(P)$, jika masing - masing (Sumber pesan dan Penerima pesan) berada pada ruang lingkup yang sama, maka pesan akan diterima oleh Penerima pesan. Proses ini akan terjadi apabila ada reaksi dari Penerima pesan dan Penerima pesan akan berubah menjadi Sumber Pesan (Yusufhadi Miarso, $1984: 47$ - 48)

Komunikasi timbal balik sering juga disebut interaksi. Interaksi edukatif dalam dunia pendidikan merupakan salah satu proses komunikasi dalam pembelajaran, di sini guru sebagai penyampai pesan (materi pembelajaran) disalurkan melalui media antara lain kata - kata, suara, isyarat, demonstrasi, lingkungan, benda tiruan, gambar atau lambang visual kepada siswa sebagai penerima pesan dan pemberi respon atas materi pembelajaran yang disampaikan oleh guru (penyampai pesan).

Media sebagai kata jamak dari kata yang berasal dari bahasa Latin "Medium" artinya "perantara" ( RHM Molenda, 1996 : 8)

Media dapat mempengaruhi siswa dan mendorong terjadinya proses belajar siswa, seperti halnya dikemukakan Miarso tentang batasan media : segala sesuatu yang dapat digunakan untuk merangsang pikiran, perasaan dan kemauan siswa , sehingga dapat mendorong terjadinya proses belajar pada diri siswa. (Yusufhadi Miarso, 1984 : 48) Media dapat disebut pula sebagai saluran informasi, senada pengertian media menurut AECT dalam Sadiman, yaitu semua bentuk saluran untuk menyampaikan informasi. Namun Briggs mengenai media lebih menekankan sarana dalam kegiatan belajar dan pembelajaran. la mengemukakan media adalah sarana fisik antara lain gambar, media cetak, kaset suara, kaset video, film bingkai diam atau bersuara, film movi yang dapat menyajikan pesan dan 
menggairahkan belajar siswa. (Arief S.Sadiman, $1988: 8$ ) Pesan menurut Romiszowski disebut media, seperti dikemukakan dalam Designing Instructional System : Media as the carriers of messages from some transmiting source (which maybe human being or an animate object) to receiver of the message (which in our case is the leaner) ( AJ Romiszoski, 1981 : 337) Sedangkan Edling dan Paulson dalam Teaching and Media, mengatakan bahwa :

"A medium broadly conceived is any person, material or event that establishes conditions which enable the learner to aquire knowledge, skill and attitude. In sense, the teacher, the texbook and school environment are media."

Pengertian media tersebut di atas dapat disimpulkan bahwa segala sesuatu yang ada di lingkungan siswa, antara lain sarana atau bentuk saluran, manusia, peristiwa yang dapat merangsang belajar, memudahkan siswa belajar dan memungkinkan siswa memperoleh pengetahuan, keterampilan dan sikap.

\section{Pengembangan Media Sederhana}

Pengembangan Media Sederhana merupakan salah satu mata kuliah yang diberikan pada Program Studi Teknologi Pendidikan. Mahasiswa dilatih cara membuat rancangan media sederhana dan membuat media sederhana untuk keperluan pembelajaran baik untuk kebutuhan lembaga pendidikan formal atau pendidikan masyarakat. Media sederhana yang dimaksud adalah brosur atau liflet, gambar, poster, bagan, diagram, flipchart, flashcard, buletin dinding, media transparensi dan sebagainya. Lulusan mahasiswa jurusan KTP diharapkan memiliki kemampuan mengembangkan media sederhana dalam berbagai bentuk, sehingga produk atau hasil karyanya dapat dimanfaatkan untuk keperluan pembelajaran.

Deskripsi mata kuliah Pengembangan Media sederhana ini adalah: Perkembangan media grafis, pengertian grafik, grafika, 
seni grafis, macam -macam huruf, menyusun huruf dan gambar, unsur disain, prinsip-prinsip disain untuk pembuatan media sederhana, merancang dan membuat media sederhana

Dalam kegiatan belajar dan pembelajaran mahasiswa dilatih dan diberi tugas merancang dan membuat media pembelajaran. Mahasiswa Jurusan Kurikulum dan Teknologi Pembelajaran terdiri dari 2 macam kelas, yaitu kelas Reguler dan kelas Non Reguler atau kelas Alih Program..Kelas reguler adalah kelas mahasiswa yang berasal dari PMDK dan hasil seleksi SPMB, sedangkan Non Reguler adalah mahasiswa alih program yang berasal dari D2, D3 dan Sarjana Muda baik dari Pendidikan maupun Non Pendidikan. Kelas Non reguler sebagian besar lulusan D2 PGSD dan pada umumnya para guru Sekolah Dasar, guru SMP dan guru SMA. Dalam Penelitian ini dibatasi pada kelas reguler, karena ingin mengetahui motivasi belajar dalam hubungannya dengan media yang digunakan oleh mereka dalam tugasnya sebagai guru di lembaga pendidikan mereka.

\section{KERANGKA BERPIKIR}

Kegiatan belajar mengajar dapat dipandang sebagai suatu proses selama siswa mengalami pengalaman-pengalaman pendidikan untuk mencapai suatu tujuan belajar yaitu hasil belajar yang telah ditentukan, sedangkan untuk mencapai hasil belajar yang diharapkan, diperlukan suatu dukungan motivasi belajar baik motivasi yang datang dari dalam diri siswa maupun dari lingkungannya.

Motivasi berhubungan erat dengan hasil belajar. Makin tinggi motivasi belajar mahasiswa , maka akan mencapai hasil belajar yang tinggi, sebaliknya makin rendah motivasi belajarnya, maka makin hasil belajarnya akan rendah.

Dapat diduga bahwa mahasiswa alih program Jurusan KTP yang memiliki motivasi belajar tinggi, maka akan mencapai hasil belajar yang tinggi pula, sedangkan yang memiliki motivasi belajar rendah, akan 
mencapai hasil belajar yang rendah pula pada mata kuliah Pengembangan Media Pendidikan I.

\section{HIPOTESIS PENELITIAN}

Berdasarkan kerangka teori dan kerangka berpikir di atas, maka hipotesis penelitian dapat dikemukakan sebagai berikut:

Terdapat hubungan berbanding lurus antara motivasi belajar dengan hasil belajar mata kuliah Pengembangan Media

Pendidikan I mahasiswa alih program jurusan KTP FIP UNJ

\section{TUJUAN OPERASIONAL PENELITIAN}

Penelitian ini dilaksanakan untuk memperoleh data empirik secara umum mengenai hubungan antara motivasi belajar dengan hasil belajar mata kuliah Pengembangan Media Pendidikan I mahasiswa alih program jurusan KTP FIP UNJ.

\section{METODOLOGI PENELITIAN}

Penelitian dilaksanakan di jurusan KTP FIP UNJ Rawamangun Jakarta Timur.

Pelaksanaannya di mulai pada awal Oktober sampai dengan Desember 2000.

Penelitian ini menggunakan metode deskriptif korelasional. Penelitian dilakukan melalui teknik survai.

Definisi operasional dari penelitian ini : 1) Motivasi belajar mahasiswa adalah gambaran data yang diperoleh dari hasil isian kuesioner tentang motivasi belajar yang berhubungan dengan mata kuliah pengembangan Media Sederhana; 2) Hasil belajar mahasiswa adalah data hasil belajar mahasiswa mata kuliah Pengembangan Media Sederhana yang diperoleh mahasiswa alih program jurusan KTP FIP UNJ.

Populasi dalam penelitian ini : seluruh mahasiswa alih program jurusan KTP Sampel: 30 orang mahasiswa yang sedang mengikuti kuliah 
Pengembangan Media Pendidikan I/Media Sederhana, semester I tahun akademik 2000/2001.

Teknik pengambilan sampel dilakukan dengan Simple Random Sampling,yaitu diambil secara acak, melalui undian. Instrumen penelitian berupa kuesioner tentang motivasi belajar mahasiswa dirancang dengan menggunakan skala Likert dengan rentang berbobot 1 sampai dengan 5 . Sebagian instrumen disusun dalam pernyataan positif yang menjawab SS (sangat setuju) berbobot 5 dan STS (sangat Tidak Setuju) berbobot 1, sedangakan instrumen dalam penyataan negatif SS berbobot 1 dan STS berbobot 5. Untuk jawaban angka 3 dianggap netral.

Butir-butir instrumen Motivasi Belajar mahasiswa Alih Program Jurusan Teknologi Pendidikan FIP Universitas Negeri Jakarta.

Instrumen ini dimaksudkan untuk memperoleh data tentang motivasi belajar mahasiswa alih program Jurusan Teknologi Pendidikan yang dihubungkan dengan hasil belajar MK Pengembangan Media Pendidikan I atau Media Sederhana.

Butir-butir instrumen disusun berdasarkan variabel-variabel intrumen dan indikator-indikator instrumen. Adapun susunan kisi-kisi di susun dalam bentuk Tabel sebagai berikut:

Tabel 1: KISI-KISI MOTIVASI BELAJAR

\begin{tabular}{|l|l|l|l|}
\hline No. & Variabel & \multicolumn{1}{|c|}{ Indikator } & \multicolumn{1}{|c|}{ No. Item } \\
\hline 1 & Motivasi & Keinginan belajar & $1,11,4$ \\
& intrinsik & Kesadaran menyelesaikan tugas & $8,10,16,28$ \\
& & Semangat belajar & $2,3,5,6,7,14,15$ \\
& & Anggapan positif terhadap & $19,20,21,22$, \\
& & mata kuliah Media Sederhana & $26,27,29,30$ \\
& Motivasi & Dorongan dari orang lain & 17,18 \\
& ekstrinsik & Lingkungan belajar & 13 \\
& & Mengerjakan tugas yang hasil karyanya & \\
& & dapat dimanfaatkan ditempat mengajar & $12,23,24,25$ \\
\hline
\end{tabular}


Agar memperoleh hasil yang andal, maka instrumen penelitian diuji coba melalui uji validitas dan reliabilitasnya.

Instrumen penelitian diujicobakan kepada 9 orang mahasiswa alih program Jurusan Kurikulum dan Teknologi Pendidikan yang pernah mengikuti kuliah Pengembangan Media Pendidikan I. Teknik analisis validitas instrumen menggunakan rumus Pearson Product Moment Setelah dianalisis hasil ujicoba menunjukkan 25 butir instrumen valid, sedangkan 5 butir instrumen dihilangkan karena tidak valid. Selanjutnya Ke- 25 butir instrumen yang valid diuji reliabilitasnya menggunakan rumus Alpha Gronbach menghasilkan r kk =0,83 >r tabel $=0,666$ pada taraf signifikan 0,05 (Lihat Lampiran 18 hal. 53 )

Data kuesioner yang telah diisi dikumpulkan dan dianalisis menggunakan bobot 0-100. Sedangkan data hasil belajar berdasarkan skor nilai akhir yang telah di bulatkan dari nilai tugas, nilai tengah semester dan nilai ujian akhir.

Analisis data menggunakan uji normalitas dari masing-masing variabel yaitu variabel motivasi belajar $(\mathrm{Y})$ dan variabel hasil belajar Mata Kuliah Pengembangan Media Pendidikan I / Media Grafis sederhana(Y).

Selanjutnya dilakukan diuji korelasi dengan menggunakan rumus korelasi Pearson Product Moment :

$r_{x y}=\frac{n(\Sigma X Y)-(\Sigma X)(\Sigma Y)}{\gamma\left[n\left(\Sigma X^{2}\right)-\left(\Sigma X^{2}\right)\right]\left[n\left(\Sigma Y^{2}\right)-\left(\Sigma Y^{2}\right)\right]}$

dan Uji t dengan rumus: $t=\frac{r_{x y} \gamma n-2}{\gamma 1-r_{x}}$

Data hasil penelitian yang dideskripsikan adalah Motivasi belajar (X) dan Hasil belajar Mata Kuliah Pengembangan Media Pendidikan I (Y) Media Sederhana mahasiswa alih program Jurusan Teknologi Pendidikan Fakultas IImu Pendidikan Universitas Negeri Jakarta. 
Data diolah dengan menggunakan teknik statistik deskriptif statistik yang terdiri dari harga rata-rata, rentang skor, simpangan baku, modus, median dan ditribusi frekuensi yang diikuti dengan grafik dan histogram.

\section{Motivasi belajar Mahasiswa Alih Program Jurusan Teknologi Pendidikan.}

Data Motivasi belajar mahsiswa alih program jurusan Teknologi Pendidikan diperoleh dari hasil isian kuesioner mahasiswa yang terdiri dari 25 butir instrumen yang telah diujicoba validitas dan reliabilitasnya. Penghitungan data setiap mahasiswa dilakukan dengan menjumlah angka dari seluruh butir instrumen yang dipilih mahasiswa dibagi 125 kemudian dikalikan 100.

Berdasarkan Penghitungan statistik skor tertinggi 98, skor terrendah 70 , harga rerata (Mean) 80,83 , rentang skor 28 , simpangan baku 8,035, modus 82 Median 82 Jumlah data 2425 ( Lihat Lampiran 4 hal. 34) dan distribusi frekuensi sebagai berikut:

Tabel 2:

DITRIBUSI FREKUENSI SKOR MOTIVASI BELAJAR MAHASISWA ALIH PROGRAM PADA PROGRAM STUDI TEKNOLOGI PENDIDIKAN

\begin{tabular}{|l|c|c|c|}
\hline No. & Kelas interval & Frekuensi absolut & Frekuensi relatif \\
\hline 1. & $70-74$ & 9 & 30 \\
2. & $75-79$ & 3 & 10 \\
3. & $80-84$ & 12 & 40 \\
4. & $85-89$ & 2 & 6,67 \\
5. & $90-94$ & 1 & 3,33 \\
6. & $95-99$ & 3 & 10 \\
\hline & Jumlah & 30 & 100 \\
\hline
\end{tabular}




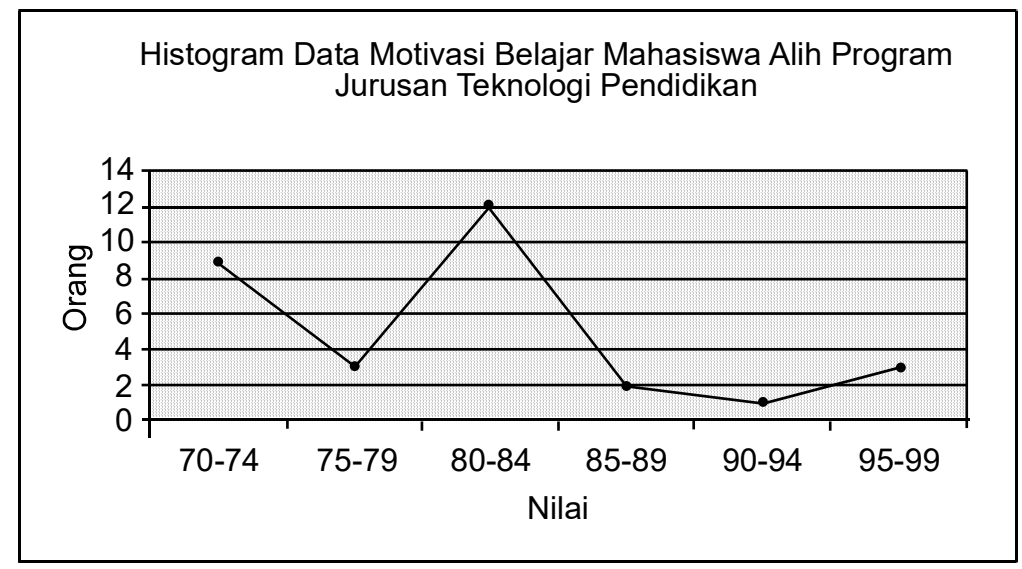

Gambar 1 : Histogram Data Motivasi Belajar Mahasiswa Alih Program Jurusan Teknologi Pendidikan

\section{Hasil Belajar Mata Kuliah Pengembangan Media Pendidikan I (Media Sederhana) Mahasiswa Alih Program Jurusan Teknologi Pendidikan}

Data hasil belajar mahasiswa alih program Jurusan Teknologi Pendidikan diperoleh dari nilai hasil belajar selama 1 semester mengikuti Mata kuliah Pengembangan Media Pendidikan I. Nilai yang diperoleh tiap mahasiswa berdasarkan Buku Pedoman Kegiatan Akademik Universitas Negeri Jakarta dengan rentang skor $0-100$.

Berdasarkan penghitungan statistik skor tertinggi 88, skor terrendah 70 , , harga rerata (mean) 78,47 , rentang skor 18 , simpangan baku 3,598 modus 79 , median 78,5, jumlah data 2354 ( Lihat Lampiran 4 hal. 34) dan distribusi frekuensi adalah sebagai berikut: 
Tabel 3:

DISTRIBUSI FREKUENSI HASIL BELAJAR MATA KULIAH PENGEMBANGAN MEDIA PENDIDIKAN I MAHASISWAALIH PROGRAM PADA PROGRAM STUDI TEKNOLOGI PENDIDIKAN

\begin{tabular}{|l|c|c|c|}
\hline No. & Kelas interval & Frekuensi absolut & Frekuensi relatif \\
\hline 1. & $70-73$ & 2 & 6,67 \\
2. & $74-77$ & 9 & 30 \\
3. & $78-81$ & 15 & 50 \\
4. & $82-85$ & 3 & 10 \\
5. & $86-89$ & 1 & 3,33 \\
& & 30 & 100 \\
\hline & Jumlah & & \\
\hline
\end{tabular}

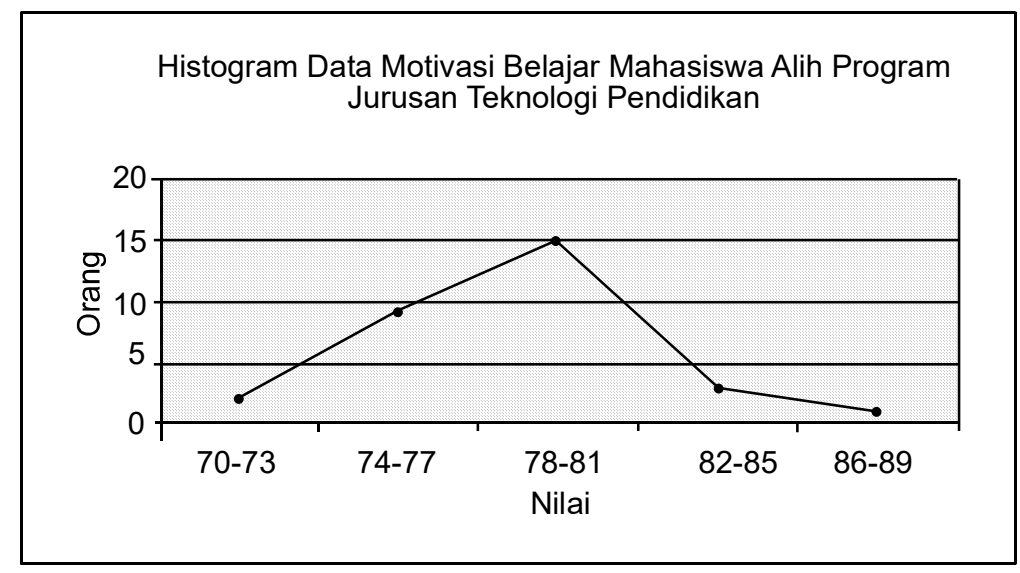

Gambar 2: Histogram Hasil Belajar Pengembangan Media Pendidikan I Mahasiswa Alih Program Jurusan Teknologi Pendidikan

\section{Uji Persyaratan Analisis}

Sebelum melakukan pengujian terhadap hipotesis penelitian, maka terlebih dahulu harus dipenuhi beberapa persyaratan. Persyaratan yang harus dipenuhi adalah diadakan analisis data variabel bebas 
Motivasi Belajar (X) dan variabel terikat Hasil belajar Mata Kuliah Pengembangan Media Pendidikan I Mahasiswa Alih program Jurusan Teknologi Pendidikan (Y) berupa uji normalitas dengan menggunakan rumus Lilifors.

\section{Uji Normalitas}

Uji normalitas untuk variabel bebas Motivasi belajar (X) dan variabel terikat Hasil belajar Mata kuliah Pengembangan Media Pendidikan I Mahasiswa Alih Program Jurusan Teknologi Pendidikan (Y) berdistribusi normal.

Uji normalitas untuk variabel Motivasi belajar $(X)$ menghasilkan $L$ hitung maksimal 0,160. Dari tabel nilai kritis Uji Lilifors dengan $N=$ 30 pada taraf signifikan $\alpha=0,05$ menunjukkan $L$ tabel 0,161 . $L$ hitung menunjukkan $<\mathrm{L}$ tabel, Hipotesis nol diterima. Jadi data $X$ berasal dari populasi berdistribusi normal ( Penghitungan lihat Lampiran 6 hal. 36).

Uji normalitas data variabel Hasil belajar Pengembangan Media Pendidikan I ( $Y$ ) menghasilkan L hitung maksimal 0,150, sedangkan $\mathrm{L}$ tabel nilai kritis Uji Lilifors dengan $\mathrm{N}=30$ pada taraf signifikan $\alpha=0,05$ adalah 0,161 . $L$ hitung menunjukkan $<L$ tabel, hipotesis nol diterima, dengan demikian data $Y$ berasal dari populasi berdistribusi normal. ( Lihat Lampiran 6 hal. 36 )

\section{UJI HIPOTESIS PENELITIAN}

Setelah melakukan uji normalitas dan linearitas sebagai persyaratan analisis data, maka dapat dilakukan uji hipotesis penelitian yang diajukan :

Hubungan Antara Motivasi Belajar (X) Dengan Hasil Belajar Mata Kuliah Pengembangan Media Pendidikan I Mahasiswa Alih Program Jurusan Teknologi Pendidikan FIP Universitas Negeri Jakarta $(Y)$.

Untuk menguji hipotesis yang berbunyi : Terdapat hubungan positif 
antara motivasi belajar (X) dengan hasil belajar mata kuliah Pengembangan Media Pendidikan I ( $Y$ ) mahasiswa alih Porgram jurusan Teknologi Pendidikan, FIP Universitas Negeri Jakarta, digunakan uji korelasi Pearson Product Moment dan Uji t.

\section{a. Uji keberartian regresi dan uji linearitas hubungan}

Uji keberartian model regresi $v=42.40+0,45 X$ menghasilkan $F$ hitung $=34,23 \mathrm{~F}$ tabel pada taraf signifikan $\alpha=0,05, \mathrm{dk}$ pembilang 1 dan dk penyebut $28=4,20$. Menunjukkan $F$ hitung $>F$ tabel, hipotesis nol ditolak dan hipotesis penelitian diterima atau gagal ditolak. Jadi kesimpulannya : model regresi v $=42,40+0,45$ $\mathrm{X}$ signifikan. (lihat Lampiran 10 halaman 41 )

Bentuk hubungan $Y$ atas $X, F$ hitung $=1,15 . F$ tabel pada taraf signifikan $=0,05$, dk pembilang 9 dan dk penyebut $19=2,43$, berarti $\mathrm{F}$ hitung < F tabel, hipotesis nol diterima dan hipotesis penelitian gagal diterima. Kesimpulannya : bentuk hubungan $\mathrm{Y}$ atas X linear.

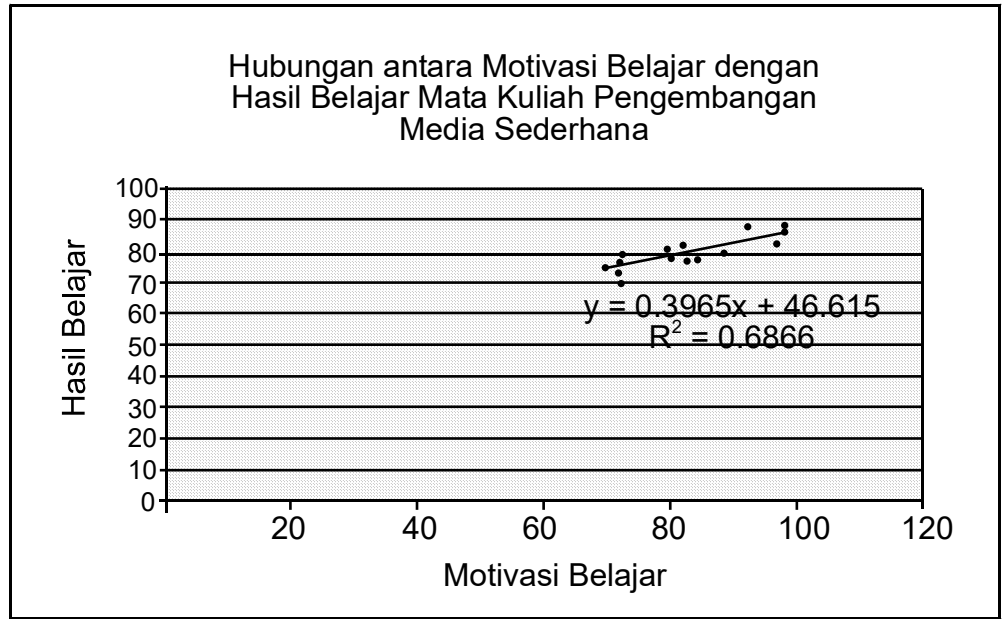

Gambar 3: Bentuk Hubungan antara Motivasi Belajar dengan Hasil Mata Kuliah Pengembangan Media Sederhana Mahasiswa Alih Program Jurusan Kurikulum dan Teknologi Pendidikan, FIP Universitas Negeri Jakarta. 


\section{b. Uji koefisien korelasi dan uji keberartian hubungan}

Uji korelasi r hitung menunjukkan 0,606, $r$ tabel harga kritik Pearson Product Moment pada taraf signikansi $\alpha=0,05 n=30$ adalah $0,361 \mathrm{r}$ hitung $0,606>r$ tabel 0,361 . Ho ditolak, $\mathrm{H}$ penelitian diterima, kesimpulannya: Hubungan antara motivasi belajar dengan hasil belajar mata kuliah Pengembangan Media I terdapat hubungan positif.

( Lihat Lampiran 7 hal. 43 ) Uji t menunjukkan $t$ hitung 4,03, t tabel pada taraf signifikansi $\alpha=0,05 \mathrm{dk}=30$ adalah 2,76 , menunjukkan bahwa $t$ hitung $>t$ tabel, Ho ditolak, dapat disimpulkan bahwa koefisien korelasi antara $\mathrm{X}$ dengan $\mathrm{Y}$ signifikan.

Hal ini menunjukkan bahwa semakin tinggi kadar motivasi belajar mahasiswa alih program jurusan Teknologi Pendidikan semakin tinggi pula kadar hasil belajar mahasiswa jurusan Teknologi Pendidikan, atau semakin rendah kadar motivasi belajar mahasiswa alih program jurusan Teknologi Pendidikan semakin rendah pula kadar hasil belajar mahasiswa alih program jurusan Teknologi Pendidikan.

Kekuatan hubungan dinyatakan oleh kontribusi motivasi belajar mahasiswa alih program jurudsan Teknologi Pendidikan terhadap hasil belajar mahasiswa alih program jurusan Teknologi Pendidikan melalui koefisien determinasi $r_{x y}{ }^{2}=0,37$ atau $37 \%$ ini berarti bahwa sebesar $37 \%$ variasi motivasi belajar mahasiswa alih program jurusan Teknologi Pendidikan memberikan kontribusi terhadap hasil belajar mahasiswa alih program jurusan Teknologi Pendidikan. Atau dapat dikatakan meningkat atau menurunnya hasil belajar mata kuliah Pengembangan Media Pendidikan I mahasiswa alih program jurusan Teknologi Pendidikan dapat dijelaskan sebesar $37 \%$ oleh motivasi belajar mahasiswa alih program jurusan Teknologi Pendidikan melalui hubungan regresi $v=46,62+0,396 X$. 


\section{PEMBAHASAN HASIL PENELITIAN}

Pembahasan hasil penelitian terhadap pengujian, dilakukan dalam bentuk deskriptif untuk setiap variabel dan termasuk dalam analisis antar variabel. Hasil analisis setiap variabel dan hasil analisis antar variabel tersebut perlu dijabarkan sebagai berikut:

Pertama, Hasil analisis deskriptaf data untuk motivasi belajar (variabel X) menunjukkan skor rerata 80,83, ini berarti bahwa mahasiswa Jurusan Teknologi Pendidikan mempunyai motivasi belajar yang tinggi. Rentang skor $70-98$, mereka yang memperoleh skor 70 adalah 1 orang yang teringgi ada 2 orang masing-masing 92 dan 98 . Analisis uji normalitas variabel $X$ (Motivasi belajar) diperoleh $L$ hitung $=0,0913<\mathrm{L}$ tabel $=$ 0,161 pada taraf signifikansi $\alpha=0,05$ dan $n=30$, karena $L$ hitung menunjukkan angka lebih kecil daripada $L$ tabel, maka data $X$ berditribusi normal Analisis uji normalitas variabel Y (Hasil belajar Pengembangan Media Pendidikan I mahasiswa alih progran jurusamn Teknologi Pendidikan) diperoleh $\mathrm{L}$ hitung $=0,160<\mathrm{L}$ tabel Lilifors $=$ 0,161 , pada taraf signifikansi $\alpha=0,05$ dan $n=30$, berarti $\mathrm{H}$ nol tolak, $\mathrm{H}$ penelitian diterima, maka data $\mathrm{Y}$ menunjukkan berdistribusi normal Hasil pengujian hipotesis mengenai hubungan antara motivasi belajar dengan hasil belajar mahasiswa alih program jurusan Teknologi Pendidikan teruji mempunyai hubungan positif, yaitu diperoleh koefisien korelasi sebesar $r=0,606$. Koefisien determinasi $\left(r^{2}\right)=0,606^{2}=0,37$ $=37 \%$, artinya sebesar $37 \%$ variasi motivasi belajar mahasiswa alih program jurusan Teknologi Pendidikan memberikan kontribusi pada variasi hasil belajar mata kuliah Pengembangan Media Pendidikan I pada semester ganjil 2000/2001. melalui model regresi $v=46,62+$ $0,396 x$

\section{KETERBATASAN PENELITIAN}

Pelaksanaan meneliti obyek penelitian, terutama dalam menjaring data telah diupayakan untuk memperoleh data seakurat mungkin, namun masih ada keterbatasan-keterbatasan dalam kegiatan penelitian ini. 
Kelemahan pengumpulan data dalam bentuk kuesioner adalah responden kurang teliti dalam membaca item-item instrumen yang tersedia dan ada yang sengaja memberikan jawaban yang tidak jujur atau asal isi saja, maka interpretasi dan kesimpulan perlu dilakukansecara hati-hati. Kesempatan untuk menemui responden sangat sulit, harus mencari waktu, hari apa mereka datang ke kampus untuk mengikuti kuliah. Pada waktu menemui para responden pada saat mereka akan kuliah waktu luangnya sangat pendek, karena mereka harus masuk kuliah. Para responden dalam waktu yang pendek tersebut kesempatan mengisi kuesioner sangat terburu-buru, jadi tidak sepenuhnya menghayati isi instrumen penelitian.

\section{KESIMPULAN}

Suatu upaya guru memudahkan siswa menangkap dan mencerna materi pelajaran adalah memanfaatkan media dalam kegiatan belajar mengajar. Pada kenyataan tidak semua guru memanfaatkan media sebagai alat bantu mengajar guru, karena : a) merasa tidak mampu merancang dan membuat media sendiri; b) Media yang tersedia tidak dimanfaatkan karena rusak atau hanya terpajang di ruang kepala sekolah; c) tidak tersedianya dana khusus untuk bahan pembuatan media.

Adanya keinginan untuk meningkatkan profesional dan meningkatkan taraf hidup guru, misalnya untuk memenuhi persyaratan kenaikan pangkat, maka para guru mulai me-masuki program strata satu di Universitas Negeri Jakarta. Salah satu program strata satu yang menjadi tempat mereka menimba ilmu adalah Program Studi Teknologi Pendidikan. Salah satu mata kuliah pada program studi ini adalah Pengembangan Media Pendidik-an I yang sangat mendukung guru untuk memiliki keterampilan merancang, membuat dan menggunakan media sederhana. Setelah menyele-saikan mata kuliah ini, para guru/mahasiswa alih program memiliki daya kreativitas yang tinggi dapat menerapkan kemampuannya merancang, membuat dan menggunakan media buatan sendiri. 
Dari uraian latar belakang, maka diteliti hubungan motivasi belajar mahasiswa alih program jurusan Teknologi Pendidikan dengan hasil belajar mata kuliah Pengembangan Media Pendidikan I

Hasil analisis data yang diawali dengan uji normalitas dan hipotesis penelitian tentang hubungan motivasi belajar dengan hasil belajar mata kuliah Pengembangan Media Pendidikan I mahasiswa alih program jurusan Teknologi Pendidikan telah terpenuhi walaupun ada kelemahankelemahan baik dari responden, instrumen penelitian, maupun waktu penelitian yang sangat terbatas. Dari hasil penelitian dapat diambil kesimpulan sebagai berikut: a)Hasil analisis hubungan antara variabel motivasi belajar dengan hasil belajar mata kuliah Pengembangan Media Pendidikan I mahasiswa alih program jurusan Teknologi Pendidikan terdapat hubungan positif. Uji normalitas menunjukkan bahwa kedua variabel signifikan; b) Sebesar $37 \%$ variasi motivasi belajar mahasiswa alih program Teknologi Pendidikan memberi kontribusi terhadap hasil belajar mahasiswa alih program Teknologi Pendidikan Mahasiswa yang diteliti pada umumnya bertugas menjadi guru. yang memerlukan alat bantu mengajar. Dengan adanya mata kuliah Pengembangan Media Pendidikan I, para responden termotivasi untuk mempelajari lebih mendalam tentang berbagai macam media pendidikan, sehingga memperoleh bekal pengetahuan keterampilan tentang media pendidikan yang dapat ditterapkan pada waktu mengajar disekolah tempat mereka bekerja.

\section{IMPLIKASI}

Beberapa temuan yang telah dikemukakan dan dibahas dalam BAB IV memiliki implikasi baik langsung maupun tidak langsung terhadap belajar yang dilaksanakan.

Berdasarkan kesimpulan diatas diperoleh hal-hal sebagai berikut:

\section{Implikasi bagi mahasiswa}

Temuan yang sudah dikemukakan terdahulu baik langsung maupun tidak langsung memiliki relevansi yaitu jika kegiatan belajar yang baik dengan didukung motivasi belajar yang tinggi akan memberikan hasil belajar yang maksimal. 


\section{Implikasi bagi lembaga profesi dan sekolah}

Dosen merupakan pengajar dan pendidik yang dapat memberikan kontribusi yang bermanfaat untuk meningkatkan hasil belajar yang maksimal, maka dosen perlu memberikan motivasi pada mahasiswa dalam setiap kegiatan pembelajaran dan perlu ditanamkan anggapan yang positif terhadap pelajaran dan mahasiswa perlu diberikan rangsangan yang menarik dalam setiap kegiatan pembelajaran agar mahasiswa memiliki motivasi yang tinggi dalam belajarnya.

\section{SARAN-SARAN}

1. Dosen hendaknya selalu memberikan motivasi, sehingga bekal yang diperoleh mahasiswa selama belajar di Perguruan Tinggi dapat menjadi bekal mengajar di tempat mereka bertugas

2. Mahasiswa hendaknya meningkatkan daya kreativitas yang tinggi dan selalu memanfaatkan media pada saat melaksanakan tugas mengajar.

3. Dari hasil penelitian ini dapat memberikan masukan bagi dosen, lembaga pendidikan, dalam rangka meningkatkan mutu pendidikan perlu diadakan penelitian lanjutan yang lebih intensif.

\section{DAFTAR PUSTAKA}

Dahar, Ratna Wilis. (1989). Teori-teori Belajar. Jakarta:PT Erlangga. Dimyati, (1994). Belajar dan Pembelajaran. Jakarta : Dep. P dan K, Direktorat Pendidikan Tinggi

Good, Thomas L. (1990) Educational Psychology, London : Longman Imron, Ali. (1996). Belajar dan Pembelajaran. Jakarta : PT Pustaka Jaya.

Miarso, Yusufhadi. Et.al. (1986). Teknologi Komunikasi. Jakarta : PT Rajawali.

Nasution, S. (1990). Didaktik Asas asas Mengajar, Jakarta: Jemmars. Rakhmat, Jalaluddin. (1994). Psikologi Komunikasi. Banding : PT Remaja Rosdakarya. 
Sadiman, Arief S. (1983). Media Pendidikan, Jakarta : PT Rajawali. Sudjana. (1989). Metoda Statistika, Bandung : Penerbit PT Tarsito Sukardi, Dewa Ktut. (1983) Bimbingan dan Penyuluhan di SD Surabaya : Usaha Nasional.

Sumidjo, Wahyu. (1994). Kiat Kepemimpinan dalam Teori dan Praktek, Jakarta: PT Harapan Masa.

Winkel, WS. (1991). Psikologi Pengajaran. Jakarta : PT Gramedia Wirawan, Sarlito S. (1976). Pengantar Psikologi, Bandung : PT Bulan Bintang. 